\title{
Problem Kosmologi Dalam Filsafat Ibnu Rusyd
}

\author{
M. Lutfi Mustofa, M.Ag \\ Dosen Mata Kuliah Studi Teologi Islam dan Sokretaris Lembaga Kajian atQuran dan Sains \\ (LKQS) UIIS Malang. Sekarang sedang menempuh Progran Doktor di IAIN Sunan Ampel \\ Surabaya
}

\begin{abstract}
Philosophical discourse of universe creation was a phenomenon which characterized the dynamic vieu's of Moslems scholars. This theme became an up to date topic as Moslems were faced with the exhaustive discussions to strengthen their beliefs on the existence of God and universe. In addition. this was also related to the great efforts made by the Moslems scholars to protect their concept on Tauhid and Aqeedah not to be contaminated by the thoughts aid concepts developed by non Moslem scholars.

This writing aims at uncovering Ibn Rusyd philosophy on cosmology. Ibnu Rusyd stated that universe was gradually created. Thus, the creation should be a process of changing one to another or change the potential into an actual creation. All these processes were done continuously in indefinite period
\end{abstract}

\section{A. Pendahuluan}

Sebagaimana telah populer dalam sejarah pernikiran Islam, masa antara abad ke 9-13 M. merupakan periode paling kontroversial tetapi produktif. Oleh karena itu, para intelektual menyebutnya sebagai the age of creative tension. Kontroversi 
ini antara lain terlihat dalam pergumulan antara kaum fuqaha dengan sufi, teolog dengan ahlul hadits dan filosof, bahkan antara sesama teolog maupun filosof hingga para sufi itu sendiri.

Salah satu tokoh utama dalam pentas pemikiran Islam abad pertengahan itu adalah Ibnu Rusyd, seorang filosof muslim yang hidup pada abad 12 M. (11261198) di Cordova Spanyol. Pada saat itu, Ibnu Rusyd terlibat "di luar arena" dalam polemik antara Ibnu Sina dan al-Ghazali. Kehadirannya bukan saja signifikan bagi usaha mengurai benang kusut pemikiran Islam, tetapi juga dalam menghidupkan kembali filsafat yang telah memasuki titik nadir. Para sejarawan menuturkan bahwa filosof muslim penganut madzhab Maliki dalam bidang fiqh itu telah menorehkan wama filsafat yang lebih spesifik. ${ }^{1}$ Pandangan ini, menurut Yusuf Musa, dilatari oleh adanya ciri khusus pada beberapa gagasan dan pemikiran Ibnu Rusyd dalam Tahafut al-Tahafut, Fashl al-Maqal dan al-Kasyf 'an Manahij al-Adillah.' Pada sebagian besar karya ini, Ibnu Rusyd bukan sekadar menunjukkan wacana dekonstruksi yang signifikan bagi perkembangan filsafat sesudahnya di Timur dan Barat, tetapi juga telah menyederhanakan pembahasan filsafatnya sehingga dapat dijangkau oleh logika awam (common sense).

Di antara tema kosmologi yang menjadi polemik abad pertengahan adalah soal etemalitas alam. Masalah ini menjadi menarik karena umat beragama di dunia Timur sedang berhadap-hadapan dalam diskusi mendalam mengenai keyakinannya masing-masing tentang Tuhan dan alam. Menurut Harun Nasution, diskursus metafisika ini sangat menyita energi dan fikiran para filosof karena terkait dengan upaya mereka mempertahankan konsepsi tauhid dan aqidah Islam dari kontaminasi berbagai paham yang berkembang di luar agama. ${ }^{3}$

Usaha Ibnu Rusyd menjelaskan bagaimana alam ini diciptakan tampak diwamai oleh Aristoteles, bahwa alam secara keseluruhannya adalah diciptakan tidak secara sekaligus. Perbuatan mencipta itu sendiri mesti berlangsung sejak azaliy, abadi serta berlangsung secara terus menerus (al-khalq al-mustamir). Menurut lbnu Rusyd, penciptaan tidak bisa sempuma dalam satu tahap sekaligus, apalagi dari sesuatu yang tidak ada sebelumnya (creatio ex nihilo). Jadi, penciptaan hanus dipahami sebagai proses merubah sesuatu menjadi sesuatu yang lain (alkhalq min al-syai) atau merubah sifat potensial pada materi pertama menjadi sesuatu yang aktual di alam wujud. Keseluruhan proses ini berlangsung secara terus menerus sejak zaman tak bermula hingga tak terhingga. 
Bagaimana Ibnu Rusyd menguraikan lebih lanjut teori kosmologi inilah yang akan menjadi pokok masalah dalam tulisan ini. Oleh karena itu, tulisan ini dimaksudkan untuk mengurai filsafat Ibnu Rusyd tentang teori etemalitas alam, penciptaan dari ada (al-khalq min al-syai') dan penciptaan secara terus menerus (al-khalg al-mustamir).

\section{B. Alam antara Huduts dan Qadim}

Sebagaimana telah tampak dalam berbagai pemikirannya, di sini Ibnu Rusyd memakai dalil Aristoteles untuk menafsirkan nash-nash agama secara rasional, berdasarkan prinsip-prinsip umum yang terdapat dalam al-Qur'an. Oleh karena itu, pembahasan Ibnu Rusyd mengenai alam semesta menunjukkan adanya kemiripan dengan madzhab Aristoteles. Ibnu Rusyd berpendapat bahwa mawjudat (alam seluruhnya) ini bukan "baru" dan "kadim" dalam arti yang sebenarnya. Alam dipandang kadim dalam arti bahwa dia ada bukan dari tidak ada dan tidak didahului oleh waktu.

Dalam Tahafut at-Tahafut, Ibnu Rusyd mengatakan ketika sampai suatu dalil pada para filosof bahwa terdapat prinsip penggerak azali yang wujud-Nya tidak berawal dan berakhir, atau perbuatan-Nya tidak boleh terlambat dari wujudNya, maka kelanjutannya ialah perbuatan-Nya mesti tidak ada permulaan pula seperti wujud-Nya. Alasannya sederhana saja, kalau perbuatan-Nya memiliki permulaan, maka ia merupakan perbuatan mungkin, bukan perbuatan mesti (dharuriy). Oleh karena itu, harus dipahami bahwa perbuatan Pencipta (fa'il, yakni Tuhan) yang tidak memiliki permulaan bagi wujud-Nya, maka perbuatan itu sama seperti wujud-Nya yang tidak bermula. ${ }^{4}$

Dari pernyataan itu, Ibnu Rusyd ingin menjelaskan bahwa perbuatan Tuhan saat menciptakan segala sesuatu telah berlangsung sejak azali (zaman tak bermula), yakni semenjak Dia ada. Apabila tidak demikian, maka sifat Maha Mencipta Tuhan itu menjadi mungkin bukan mesti. Artinya, bahwa Tuhan boleh mencipta dan boleh tidak. Jika ini yang terjadi, maka pemahamannya adalah bahwa Tuhan pernah "tidak berbuat alias menganggur". Hal ini jelas bertentangan dengan sifat Maha Mencipta-Nya. 
Atas dasar argumen ini, untuk memperjelas keazalian perbuatan Tuhan, Ibnu Rusyd dengan nada bertanya mencoba menegaskan, apa keberatannya bagi Tuhan kalau sebelum perbuatan-Nya yang sekarang telah ada perbuatan-Nya yang terdahulu, dan begitu seterusmya sampai tidak berkesudahan seperti wujud-Nya yang juga tidak berkesudahan. Dengan begitu, menurut Ibnu Rusyd, Tuhan adalah Pencipta tampa kesudahan. Artinys kalau wujud-Nya tidak beriningan dengan zaman dan tidak bisa diliputi dari kedua ujungnya, maka konskuensinya ialah perbuatanNya mesti juga tidak diliputi atau beniringan dengan zaman. Karena, setiap perbuatan tentu tidak akan terlambat dari wujud dzat yang mempunyai perbuatan tersebut, kecuali kalaw wujudnya tidak sempuma atau bukan wujud yang mempunyai pilihan.

Ketika menanggapi pandangan syar'i yang menetapkan huduts-nya alam, Ibnu Rusyd memahaminya dengan pengertian yang jauh berbeda dari kaum Asy'ariah. Menurut Ibnu Rusyd, selama perbuatan itu tetap disebut sebagai perbuatan maka ia adalah diciptakan. Hanya, ketika perbuatan itu terkait dengan pelaku yang kadim, maka perbuatan yang dicipukan tersebut mesti tidak mempunyai awal dan akhir. Lebih lanjut Ibnu Rusyd mengatakan, oleh karena itu ulama merasa kesulitan untuk menyebut alam ini "kadim" dan Allah Swt. juga kadim. Alasannya sederhana saja, mereka itu tidak memahami makna kadim, kecuali bahwa kadim itu adalah sesuatu yang tidak memiliki 'illah (sebab) bagi wujudnya (al-qadim ma la 'illata lahu). ${ }^{5}$ Dalam hal ini, Ibnu Rusyd melihat sebagian ulama Islam benarbenar cendenung kepada makna tersebut.

Dalam Fashl al-Maqal, Ibnu Rusyd berargumen bahwa jika penjelasan syar'i itu diteliti maka akan didapati bahwa yang diciptakan Tuhan sebenarnya adalah bentuk alam. Adapun hakikat wujud alam dan zaman ini berlangsung terus menerus dari kedua ujungnya, yakni tidak pernah terputus. Hal ini didasarkan oleh Ibnu Rusyd kepada firman Alah Swt.:

Dan Dialah yang menciptakan langit dan bumi dalam suatu tahapan (periode) dan adalah singgasana-Nya (sebelum itu) di atas air. (QS. Hud/ 11:7)

Ayat ini menjelaskan bahwa sebelum adanya alam semesta telah ada wujud lain berupa 'arsy dan air, serta ada zaman lain selain zaman yang berkaitan dengan bentuk alam ini, yaitu gerakan falak. Sebagaimana firman Allah Swt.: 
Kemudian Allah menuju kepada penciptaan langit, dan langit ketika itu masih merupakan asap. (QS. Fushshilat/41:11)

Menurut Ibnu Rusyd, lahiriah ayat ini menghendaki bahwa alam semesta diciptakan dari sesuatu (khuliqa min al-syai ). ${ }^{6}$ Dalam kaitan ini, Ibnu Rusyd menegaskan bahwa kaum teolog ketika berbicara tentang alam juga tidak mendasarkan pada nash syar'i yang jelas. Mereka hanya melakukan tekwil terhadap ayat, sebab tidak ada satu ayat pun yang menegaskan bahwa Allah Swt. "mengada" bersama-sama dengan ketiadaaan semata.'

Dengan demikian, Ibnu Rusyd juga mampu menghadirkan nash-nash sebagai dalil yang kuat tentang kadimnya alam, meskipun kekadiman itu sendiri dari suatu jenis yang telah ditetapkan. Untuk itu, tidak dapat diragukan lagi bahwa dalam filsafat Ibnu Rusyd, sebagaimana juga diyakini oleh umat Islam pada umumnya, bahwa Allah Swt. adalah kadim. Kekadiman ini memastikan bahwa perbuatanNya juga kadim sebagaimana wujud-Nya. Dengan kata lain, jika alam ini merupakan hasil dari perbuatan Tuhan, maka alam ini mesti kadim sebagai ciptaan-Nya.

Kendatipun demikian, tidak dimaksudkan bahwa kadimnya alam itu sama dengan kadimnya Tuhan, yakni tidak memiliki 'illah seperti wujud Tuhan. Bagi Ibnu Rusyd, yang kadim selain Tuhan bisa jadi memiliki 'illah. Oleh karena itu, dari aspek pemikiran ini alam adalah "baru", dalam arti sebagai $m a$ 'lul, bukan dengan makna yang memiliki permulaan dari segi zaman. Alam ini disebut taqaddum zamaniy, karena huduts-nya alam ini telah sempuma sejak zaman tak bermula (azaliy).

Dengan diibaratkannya huduts sebagai bermakna ma'luliyah oleh Ibnu Rusyd, al-Jurjani membagi jenis huduts ke dalam tiga makna yang berbeda. Periama, yang umum dipahami orang sebagai gambaran terhadap adanya sesuatu setelah tidak adanya. Kedua, huduts zamaniy, yakni adanya sesuatu itu didahului dengan tiada, namun ia mendahuluinya dari segi zaman. Ketiga, sesuatu yang bagi wujudnya berhajat kepada yang lain. ${ }^{8}$

Berdasarkan beberapa argumen filosofis tentang makna huduts dan kadim serta beberapa nash syar'i, sepertinya Ibnu Rusyd bermaksud memberi isyarat bahwa pandangan filosofis tentang kadimnya penciptaan alam tidak bertentangan dengan gagasan qur'ani. Dengan alasan, pemahaman tentang "baru" yang disebut dalam al-Qur'an tidak selalu menghendali kemestian terdapatnya unsur-unsur 
zaman. Oleh karena itu, dalam pandangan Ibnu Rusyd, kaum Asy'ariah telah melakukan kesalahan dalam memahami ayat-ayat al-Qur'an dengan menyatakan bahwa yang huduts mesti didahului oleh waktu dan ketiadaan. Atas dasar itulah, dalam Manahij al-Adillah, Ibnu Rusyd kembali menegaskan bahwa argumen kaum Asy'ariah tentang barunya alam tidak bersifat burhaniy, bahkan tidak pula syar'iy. ${ }^{9}$

Lebih lanjut, Ibnu Rusyd menegaskan bahwa akidah tidak menuntut lebih dari pengetahuan bahwa alam ini memiliki 'illah. Ketahuilah bahwa yang dituju oleh syari'at tentang pengetahuan kealaman adalah alam sebenamya ciptaan Allah Swt. Masih menurut lbnu Rusyd, sesungguhnya dapat diambil kesamaan antara wujud sesuatu yang hakiki dengan wujud yang kadim. Apabila kesamaan sesuatu terhadap yang kadim melebihi kesamaannya terhadap muhdats, maka ia disebut qadim. Sedangkan apabila kesarnaannya cendenung kepada muhdats, maka disebut huduts. ${ }^{10}$ Alam sebagai ciptaan Allah adalah kadim jika dipandang sebagai hasil dari perbuatan-Nya. Sebaliknya, alam ini baru jika dipandang dari segi bahwa ia memiliki 'illah, yaitu Allah Swt. Oleh karena itu, dengan pandangan seperti ini memungkinkan untuk mengatakan bahwa alam ini diciptakan semenjak azali, atau alam ini baru tetapi kadim penciptaannya.

Dengan demikian, barunya alam harus dipahami bahwa ia diciptakan secara terus menerus semenjak azali (creatio ab aetarno), bukan diciptakan secara terputus-putus. Dari sinilah, lbnu Rusyd berbeda pandangan dengan kaum teolog tentang segi penciptaan yang kekal itu. Bagi Ibnu Rusyd, pengertian ihdats harus berlangsung sejak azali dan terus menerus, sedang kaum teolog memberinya makna secara terputus-putus dan bukan sejak azali.

Pandangan Ibnu Rusyd ini didasarkan pada argumen bahwa penciptaan secara terus menerus lebih menunjukkan kekuasaan Sang Pencipta. Sedang penciptaan secara terputus-putus mengisyaratkan kepada penetapan lemahnya kekuasaan pada diri sang pencipta. Selain itu, penciptaan secara terputus-putus juga mengandung arti menyedikitkan peranan $\mathrm{Fa}^{\prime} \mathrm{il}$ yang berkuasa atas segala sesuatu. Demikian lbnu Rusyd menjelaskannya dalam Tahafut al-Tahafut:

Adapun jika alam ini kadim karena dzatnya dan maujud bukan dari segi ia digerakkan, karena setiap yang digerakkan itu tersusun dari bagianbagian yang baru, maka artinya alam ini tidak memiliki pencipta. Sedangkan jika alam ini kadim dalam arti diciptakan secara terus menerus, atau bagi penciptaannya itu tidak ada awal dan akhir, maka sesungguhnya sesuatu 
Yang dihasilkan dari penciptaan semacam itu lebih berhak menyandang atribut ihdats (diciptakan) dari pada yang dihasilkan dari penciptaan secara terputns-putns."

Dalam penjelasan soal perbedaan madzhab Plato dan Aristoteles tentang apakah alamini memilikifa'ilataukah tidak, Ibnu Rusydmengatakan bahwa Plato berpendapat tentang barunya alam. Lebih jelasnya, menurut Plato alam memiliki pencipta.Sedangkan A ristoteles menyifati alam dengan kadim. Aristoteles tidak pernah mengatakan bahwa alam memiliki pencipta, tetapi alam bersandar pada adanya Penggerak yang tidak bergerak. Pandangan paling akhir inilah yang dijadikan dasar dalam pengikut Aristoteles untuk meniscayakan $F_{a}^{\prime} i l$ (pencipta) bagi adanya alam. Alasannya, seperti disinyalir oleh Ibnu Rusyd dalam Tahafut al-Tahafut:

Pemberi gerak adalah fa'il bagi gerak yang hakiki. Jika jisim-jisim samawi tidak sempuma wujudnya kecuali dengan adanya gerak, maka pemberi gerak tersebut adalah pencipta jisim-jisim samawi itu sendiri. ${ }^{12}$

Argumen ini dijadikan dasar banyak pemerhati filsafat Islam, bahwa Ibnu Rusyd telah menjadikan apa yang disebut sebagai Penggerak Pertama dalam madzhab Aristoteles sebagai pencipta alam semesta. Di kemudian hari, takwil Ibnu Rusyd tersebut dikenal sebagai pemikiran cerdas dan argumentatif tentang dalil gerak Aristoteles.

Oleh karena itu, menjadi tidak beralasan sebagai analis sejarah yang mengatakan adanya "kekacauan" dalam filsafat kosmologi Ibnu Rusyd. Sebab, Ibnu Rusyd tetap setia mengatakan nalar-nalar filosofis, baik dalam karya-karya filsafat. Hanya, memang harus diakui bahwa Ibnu Rusyd memiliki padangan lain yang disesuaikan dengan jalan pikiran orang-orang awam, tetapi tetap dilakukan di atas landasan filsafat dan pikiran rasional.

Disamping itu pada umumnya para analis sejarah menilai madzhab kosmologi Ibnu Rusyd tidak jauh berbeda dengan madzhab filosof muslim yang lain. Di antaranya, Ibnu Sina yang berpendapat bahwa alam ini diciptakan dalam keadaan baru dari segi zaman, tetapi ia baru dari segi bahwa dzatnya diciptakan. Artinya, ke-huduts-an tersebut tidak didahului atau berkaitan dengan zaman. Dengan 
begitu, tidak dapat disangsikan bahwa Aristoteles menupakan muara pemikiran filsafat Islam yang menegaskan bahwa zaman bukanlah sesuatu yang ada di luar alam, karenanya zaman tidak akan pernah ada sebelum alam ini ada. Perbedaamma hanya dari segi pahwa menunu Ibnu Sina, penciptaan mesti benmakna mengeluarkan bentuk yang baru dari materi pertama yang kadim, dan pernberi bentuk adalah Allah Swt. Sedangkan bagi Ibru Rusyd, bentuk sendiri kadim sebagaimana kadinmrya materi pertima Selain itu, makna perbuatan mencipta bagi Ibnu Rusyd adalah menggerakkan sesuatu yang potensial dalam materi agar menjadi aktual. Dengan kata lain, meminjam pengertian Aristotelian, penciptaan adalah merubah materi dari keadaan potensial menjadi keadaan aktual.

Dengan demikian, untuk menepis adanya keraguan tentang problematika gadim dan huduts-nya alam dalam filsafat lbnu Rusyd, maka harus dibedakan dahulu secara jelas antara azali dan zaman. Menurut Ibnu Rusyd, seperti dikatakan Aristoteles, zaman adalah ukuran gerakan sesuaru yang mengiringi alam dunia ('alam al-kaun wa al-fasad). Jika dikatakan alam kadim, artinya zaman pun juga mesti kadim seperti halnya alam. Sedangkan azali mengarah kepada sesuatu yang bergerak secara terus menerus sejak zaman tak bermula, misalnya langit pertarna. Disamping itu, azali juga berkonotasi kepada sesuatu yang tidak bermasa dan tidak bergerak sama sekali, misalnya Penggerak yang tidak bergerak (Tuhan) dan al'uqul al-mufarrigah. Dengan demikian, jelas bahwa pengertian kedua dari istilah azali ini yang membedakan antara azali dengan zaman, karena pengertian itu pula yang membedakan antara Allah Swt. dengan segala maujud lain. Adapun zaman terikat dengan perubahan gerak, karena ia merupakan ukuran gerak segala wujud yang bergerak.

\section{Penciptaan dari "Ada" (al-Khalq min al-Syai")}

Ibnu Rusyd berpendapat, setiap bagian dari segala yang ada merupakan kenusakan bagi sehagian yang lain. Tetapi, kenusakan dari setiap bagian itu sekaligus merupakan penyebab bagi adanya bagian yang lainnya lagi. Jika tidak demikian, maka adanya sesuatu bisa bukan berasal dari sesuatu yang lain. Padahal, makna penciptasn (takowwun) adalah merubah sesuatu yang potensial menjadi aktual. Jadi, sesuatu yang tidak ada ('adam al-syai ) mustahil berubah menjadi ada (alkaun). ${ }^{13}$

Ulul Albab, Vol. 4 No. 2, 2002 
Oleh karena itu, Ibnu Rusyd merasa perlu membandingkan antara pemahaman filosof dan teolog tentang perbuatan mewujudkan (al-ijad) atau menciptakan (al-khalq) dalam pernyataannya sebagai berikut:

Sesungguhnya perbuatan $f a$ 'il (menurut teolog) terkait erat dengan penciptaan mutlak, yaitu menciptakan sesuatu yang tidak ada sebelumnya, bukan dengan potensi juga bukan menciptakan sesuatu yang mumkin dari potensialitas ke aktualitas. Adapun perbuatan fa'il dalam pandangan filosof, tidak lain adalah mengeluarkan sesuatu dari potensialitas menuju aktualitas. Hal ini menurut mereka berkaitan dengan adanya maujud dari dua sisi (ijad dan $i^{\prime} d a m$ ). Apabila ijad dimaknai dengan meniadakan sesuatu dari wujudnya yang potensial ke aktual, sehingga hilanglah ke- 'adam-annya, maka i'dam adalah meniadakan wujud yang aktual kepada wujud yang potensial sehingga terjadilah ke-'adam-annya. ${ }^{14}$

Penciptaan, menurut Ibnu Rusyd, bukanlah mengeluarkan sesuatu dari yang tidak ada (creatio ex nihilo) seperti dipahami oleh kaum teolog. Tetapi, penciptaan adalah merubah sesuatu dari potensial menjadi aktual. Artinya, segala yang ada ini mesti mengalami perubahan. Dengan begitu, harus ada wujud materi yang azali, abadi dan kadim serta diikuti dengan bentuk-bentuk yang azali. Melalui pandangan ini, Ibnu Rusyd ingin mempertemukan antara konsep 'illah-nya Aristoteles, yaitu Penggerak yang tidak bergerak dengan konsep "Tuhan sebagai Pencipta segala sesuatu" dalam ajaran Islam. Alasannya, agar konsep Tuhan dalam filsafat Aristoteles yang semula hanya sebagai "sebab tujuan" berubah menjadi Pencipta.

Dengan demikian, penciptaan dalam filsafat Ibnu Rusyd seperti ditegaskan oleh Mahmud Khudairy, ${ }^{15}$ tidak bermakna $i b d a{ }^{\prime}$ yang konotasinya adalah penciptaan dari tiada (creatio ex nihilo). Sebaliknya, penciptaan bermakna ijad dan takwin, dengan konotasi penciptaan dari sesuatu yang telah ada semenjak azali. Oleh karena itu, alam senantiasa berada dalam proses pembentukan wujud secara terus menerus semenjak zaman tak bermula. Artinya, alam tidak tercipta secara sekaligus dari sesuatu yang tidak ada.

Jadi, menurut Ibnu Rusyd alam adalah kadim, seperti halnya materi pertama. Namun materi sendiri adalah diciptakan Tuhan semenjak qidam. Dengan demikian, dapat dikatakan bahwa dalam filsafat Ibnu Rusyd terdapat dua tahap penciptaan. Pertama, Tuhan menciptakan materi pertama (al-hayula al-ula) semenjak qidam. Kedua, Tuhan menciptakan alam semesta dari materi yang semenjak qidam pula. 
Adapun makna penciptaan dalam tahap kedua ini adalah mengeluarkan sifat potensial pada materi menjadi sesuatu yang aktual. Dengan catatan, bahwa tahap penciptaan kedua mesti dipahami berlangsung secara terus menerus dan berkesinambungan semenjak azali hingga tak terhingga. Bila didasarkan atas pemahaman di sini, maka penciptaan dari tiads, seperti dikemukakan teolog, seharusnya dipahami dengan pengertian penciptaan materi pertama tadi, bukan penciptaan alam semesta. ${ }^{16}$

Dari teori tentang penciptaan dan asal usul alam semesta, Ibnu Rusyd memang berpijak di atas dasar metafisika Aristoteles sekaligus memadukannya dengan prinsip penciptaan dalam ajaran Islam. Oleh karena itu, konsep 'illah Aristoteles yang menegaskan adanya 'illah gha'iyyah (sebab tujuan), dalam arti seluruh maujud senantiasa bergerak ke arah 'illah gha'iyyah karena didorong oleh rasa rindu, maka dalam filsafat Ibnu Rusyd berubah menjadi bukan sekadar 'illah gha'iyyah, tetapi juga sebagai 'illah fa'iliyyah (sebab penciptaan). Ini artinya, Ibnu Rusyd bukan saja memahami konsep 'illah Aristoteles, tetapi juga menjadikan potensial dan aktual sebagai konsep yang signifikan dalam filsafat kosmologinya. Selain itu, ia juga menjadikan konsep terakhir ini sebagai alat untuk membedakan antara Tuhan sebagai pencipta mumi dengan alam semesta yang memiliki sifat potensial dan aktual.

Sebagian pengkaji filsafat menilai bahwa Ibnu Rusyd memiliki dua pendapat tentang asal-usul alam. Kepada masyarakat awam, Ibnu Rusyd tidak berpendapat tentang kadimnya alam, hanya sekadar mengemukakan teorinya tentang penciptaan alam. Sedangkan dalam beberapa kitabnya untuk kajian filosofis, ia dengan tegas menguraikan argumentasi tentang kekadiman alam. ${ }^{17}$

Walaupun demikian, pada hakikatnya Ibnu Rusyd melakukannya sekadar untuk menjaga keutuhan teorinya pada setiap karya-karyanya. Penilaian ini sebagaimana dikutip Khudairy dari Ibrahim Madkour, bahwa yang dimaksud dengan kadimnya materi adalah materi itu kadim hanya dari segi zaman, bukan dalam pengertian tidak memiliki 'illah atau tidak diciptakan oleh Tuhan. Sedangkan ketika Ibnu Rusyd mengingkari kadimnya materi dalam karya rekonsiliasinya, hal itu dilakukannya sebatas untuk menunjukkan kejelasan akan penolakannya terhadap pemikiran-pemikiran tentang tidak adanya 'illah bagi materi. Kecuali itu, juga untuk menolak pendapat bahwa materi adalah 'illah bagi dirinya sendiri, sehingga tidak ada bedanya dengan dzat Tuhan. 
Argumentasi yang cukup kuat untuk menunjukkan keabsahan pandangan tersebut, Ibnu Rusyd dalam banyak karya filosofisnya senantiasa menegaskan dhahimya syara' yang mengisyaratkan penciptaan dari sesuatu (al-khalg min alsyai') dan dalam suatu zaman. Hal ini sejalan dengan upayanya untuk memberi penjelasan yang lebih dekat kepada orang-orang yang tidak mampu menghadirkan gambaran tentang adanya wujud sesuatu tidak dari sesuatu. Apalagi adanya sesuatu itu di luar zaman. Dalam hal ini, Ibnu Rusyd mensitir firman Allah Swt.:

Dan Dialah yang menciptakan langit dan bumi dalam enam tahapan dan singgasana-Nya (sebelum) itu ada di atas air. (QS. Hud/11:7)

Ayat tersebut pada dhahimya menghendaki adanya wujud sebelum wujud alam ini, yakni 'arsy dan air, serta menuntut adanya "zaman" sebelum zaman ini, yaitu zaman yang menyertai wujud alam semesta. Untuk memperkuat hal ini, Ibnu Rusyd kembali memaparkan firman Allah Swt.:

Kemudian Allah menuju penciptaan ruang alam (al-sama') yang ketika itu penuh dengan embun. (QS. Al-Fushshilat/41:11)

Bagi Ibnu Rusyd, ayat ini dengan jelas memberikan penuturan bahwa ruang alam (al-sama') diciptakan dari sesuatu. ${ }^{18}$

Penciptaan dari sesuatu tersebut tidak lain adalah makna dhahiri ayat, yakni suatu makna yang digali berdasarkan analogi (qiyas) kepada yang nyata. Makna ini sendiri masih membutuhkan kepada takwil bagi para filosof, agar tidak disalahpahami orang awam. Dari sisi ini, para teolog telah melakukan kesalahan besar dengan menyajikan hasil-hasil takwilnya terhadap masyarakat terbuka. Oleh karenanya, dalam al-Manahij Ibnu Rusyd menegaskan:

Adapun metode yang ditempuh oleh kebanyakan ulama dalam menggambarkan makna penciptaan adalah dengan metode analogi terhadap yang empiris, meskipun tidak ada contohnya di alam nyata. Halini dikarenakan tidak mungkin bagi ulama menggambarkan hakikat makna penciptaan dengan sesuatu yang tidak ada contohnya pada alam nyata. Allah Swt. menjelaskan bahwa penciptaan alam ini terjadi dalam suatu masa dan Dia menciptakannya dari sesuatu, karena di alam nyata tidak dikenal sesuatu yang disusun kecuali dengan sifat ini. Oleh karena itu, hendaknya ulama tidak mentakwilkan sesuatu selain dari makna ini. Adapun ketika dikatakan kepada mereka bahwa keyakinan syara' tentang alam adalah diciptakan dari selain sesuatu dan tidak pada suatu zaman, maka pendapat itu adalah sebagai pandangan yang tidak mungkin dipahami ulama, apalagi jumhur. ${ }^{19}$ 
Sesungguhnya dzahimya ayat al-Qur'an tentang penciptaan sesuai dengan jalan pemikiran kaum filosof, sehingga tidak perlu ditakwilkan lagi. Agama sendiri dengan tegas menyatakan bahwa alam diciptakan oleh Tuhan dari sesuatu. Hanya, yang menjadi persoalan adalah apakah agama telah menyatakan bahwa alam ini kadim dari segi zaman, atau dengan makna lain, apakah agama juga menyatakan bahwa Allah Swt. menjadikan alam tidak dalam suatu zaman? Dalam hal ini lbnu Rusyd menyatakan:

Suatu hal yang mengherankan....bahwa tamtsil yang dibuat oleh syara' mengenai penciptaan alam sesuai dengan makna "huduts" yang terdapat di alam nyata, tetapi syara' tidak menjelaskan dengan lafadz ini. Hal itu hanya merupakan peringatan dari syara' untuk para ulama agar membuktikan bahwa barunya alam tidak seperti sifat baru yang terdapat dalam kenyataan. Syara' hanya mengungkapkan dengan lafadz al-khalq dan futhur. Lafadz-lafadz ini sangat sesuai untuk menggambarkan dua makna sekaligus, yaitu menggambarkan sifat baru yang terdapat di alam nyata dan mengambarkan sifat baru yang didukung oleh argumentasi ulama tentang hal yang ghaib. Dengan demikjan, penggunaan kata-kata huduts atau qadim merupakan suatu bid'ah dalam syara'. ${ }^{20}$

Adapun hal yang mengkhususkan kaitan antara penciptaan dengan zaman, harus dilakukan terhadap ayat-ayat al-Qur'an. Bahkan, dalam hal ini al-Qur'an sendiri telah mengisyaratkan ketika menggunakan lafadz al-khalg sebagai ganti atas lafadz ihdats. Meskipun dengan lafadz yang terakhir ini gambaran al-Qur'an tentang penciptaan sebenamya sudah sesuai. Hal ini dikarenakan, seolah-olah makna ihdats tersebut mengisyaratkan pada para filosof akan pentingnya takwil. Dengan demikian, dapat dipahami bahwa alam bukan muhdats dalam pengertian tradisional. tetapi memang muhdats yang qadim.

Kembali pada penilaian para pemerhati di atas, ada sebagian lagi yang berpendapat sebaliknya, bahwa materi pertama dalam filsafat Ibnu Rusyd bukanlah ciptaan Tuhan. Mereka mengira bahwa materi pertama dalam konsepsi Ibnu Rusyd sama dengan sesuatu yang tidak berwujud. Materi itu merupakan suatu potensi mumi yang tidak terikat oleh ruang dan waktu. Oleh karena itu, bila demikian tidak mungkin materi tadi berasal dari ciptaan Tuhan. Menurut mereka, materi tersebut kekal dan senantiasa ada bersama Tuhan. Para sejarawan juga menyangkal bahwa dalam pandangan Ibnu Rusyd perbuatan Tuhan sebatas mengeluarkan bentukbentuk sesuatu yang masih bersifat potensial dalam materi menjadi aktual. ${ }^{21}$ 
Kemungkinan para pemerhati itu telah salah dalam memahami filsafat Ibnu Rusyd. Mereka beranggapan bahwa menurut Ibnu Rusyd kekadiman materi mengandung arti tidak diciptakan oleh Tuhan. Hal ini dapat dimaklumi, sebab mereka meneliti pemikiran Ibnu Rusyd hanya melalui kitab-kitab syarah filosof muslim Cordova tersebut. Padahal, apabila mereka memahami langsung karya-karya Ibnu Rusyd, maka akan jelas bagi mereka bahwa sesungguhnya Ibnu Rusyd telah melakukan distingsi tentang pengertiankekadiman alam semesta. Dengan demikian, apabila dilihat dari perspektif ini memang beralasan pendapat Ibnu Rusyd tentang kekadiman alam dan materi pertama tersebut. Bahkan, bisa jadi mereka akan turut mengatakan bahwa pendapat Ibnu Rusyd memang sesuai dan tidak bertentangan dengan nash-nash syar'i sendiri.

Disamping itu, adapeneliti lainyang telah salah dalammemberikan kesimpulan akhir terhadap takwil filsafat Ibnu Rusyd sebagai takwil Aristoteles mumi, sehingga ketika sampai pada persoalan tentang asal-usul alam, mereka menyatakan bahwa Ibnu Rusyd menganggap Penggerak Pertama hanya sebagai 'illah gha'iyyah, bukan 'illah fa'ilah. Penilaian ini didasarkan pada pandangan Ibnu Rusyd bahwa setiap penggerak dari para penggerak langit (aflak) tidak hanya melahirkan "akal" yang khusus pada suatu langit, tetapi juga "akal" tertinggi ( $a l$ - "aql al-a 'la). "Akal" tertinggi inilah yang disebut sebagai 'illah pertama. Tetapi, 'illah pertama yang dimaksudkan di sini tidak menunjukkan bahwa setiap sesuatu keluar darinya, dia hanya merupakan sebab akali ('illah ma'qulah) dan ma'qul sendiri menjadi 'illah bagi 'aqil. Singkat kata, menurut pandangan ini, Tuhan dalam filsafat Ibnu Rusyd adalah 'illah gha'iyyah bukan 'illah fa'iliyah. Disamping itu, anggapan bahwa setiap esensi itu adalah 'aqil dan ma' 'qul - -yang dengan makna ini sangat mungkin menjadi 'illah bagi segala yang ada, karena setiap yang ada tadi dapat mempersepsi esensi dengan metode akali-maka ujung-ujungnya pemilik pendapat ini akan berkesimpulan bahwa lbnu Rusyd tidak menyatakan tentang adanya pencipta bagi alam dan juga tidak ada pelimpahan secara paralel. ${ }^{22}$

Atas dasar adanya perbedaan penilaian terhadap filsafat Ibnu Rusyd di atas, maka ada satu hal yang perlu ditegaskan, bahwa materi pertama bukanlah sesuatu yang bersifat materi juga bukan esensi yang dapat diaktualkan. Tetapi, materi pertama merupakan sesuatu yang mungkin bisa menjadi jisim ketika ia disatukan dengan "bentuk" yang bersifat materi (al-shurah al-hayulaniyah). Materi pertama tidak lain adalah potensi mutlak menurut makna Aristotelian. Potensi mutlak itu 
sendiri, juga terbatas sebagai kemunglinan-kemungkinan dan persiapan untuk eksis. Sampai di sini, terkesan bahwa Ibnu Rusyd ingin merekonsiliasi madzhab Aristoteles dengan pernikiran tentang kadimnya materi yang wujudnya manafikan Tuhan dalam suatu zaman bersama-sama ketiadaan. Menurut Ibnu Rusyd, ketiadaan mutlak adalah sesuatu yang tidak mempunyai wujud sempurna, sebagaimana hal ini diyakini oleh Aristoteles sendiri.

Dengan perspektif yang berbeda dari para pemerhati terdahulu, ada suatu penilaian yang ingin menempatkan filsafat Ibnu Rusyd secara lebih proporsional. Dalam pandangan ini, Ibnu Rusyd bukan seorang materialis mumi, juga bukan seorangidealis religius sejati, tetapi lebih sesuai sebagai filosof muslim yang berusaha merambah jalan tengah di antara dua belantara pemikiran. Kaum materialis mengatakan bahwaalam ini bersifat azali dan abadi, sebab sesuatu tidak mempunyai permulaan dan akhir. Selain itu, materi bagi mereka tidak akan pernah menjadi baru ataupun rusak melainkan hanya tunduk pada pergantian dan perubahan. Kaum materialis juga menolak kisah penciptaan sebagai digagas oleh Ibnu Rusyd, yaitu gagasan tentang perjalanan masa yang kadim, konsep penciptaan dalam agamaagama samawi seperti prinsip penciptaan dari tiada (ceatio ex nihilo) hingga konsep tentang barunya alam sebagai dipahami oleh kaum Asy'ariah dan para teolog masehi lainnya.

Dalam kaitan itulah, Ibnu Rusyd dipandang mampu mempertemukan dua spektrum pemikiran tersebut dengan metode takwilnya. Alasannya, Ibnu Rusyd dipandang berhasil menjelaskan ide tentang tidak adanya wujud yang bertentangan antara konsep yang menyatakan keazalian alam dengan adanya Pembuat Pertama (Tuhan) terhadap alam. Ibnu Rusyd mensintesakan keduanya dalam sebuah pernyataan bahwa alam ini azali dan abadi, namun ia tetap diciptakan oleh Allah Swt. sebagai Pembuat Pertama. Ibnu Rusyd juga menegaskan bahwa keazalian alam dan keabadiannya merupakan konsekuensi logis dan wajar dari pengakuan adanya al-'Illah al-Ula, yakni pembuat wujud keseluruhan alam semesta. ${ }^{23}$

Dari berbagai penjelasan di atas, tampak bahwa dalam filsafat Ibnu Rusyd memang tidak terdapat pemikiran tentang penciptaan dari tiada (creatio ex nihilo) sebagaimana dipahami teolog. Sebaliknya, penciptaan mesti berasal dari sesuatu yang telah ada sebelumnya, yaitu materi pertama, meskipun materi sendiri diciptakan oleh Allah Swt. Sedangkan perbuatan mencipta merupakan proses mengeluarkan hal potensial dalam materi yang azali agar menjadi sesuatu yang aktual. Sebagai 
konsekuensi atas penolakannya terhadap adanya yang baru dengan genus (dzat), yakni penciptaan dari tiada, maka Ibnu Rusyd menolak pula adanya "ketiadaan mumi" dan "kerusakan mumi". ${ }^{24}$ Selain itu, Ibnu Rusyd juga menawarkan dua bentuk wujud, yaitu wujud potensial dan wujud aktual.

Dalam rangka menafsirkan masalah metafisika ini, Ibnu Rusyd menyatakan apabila diajukan suatu pertanyaan dalam segi apakah menurut anda keterkaitan antara perbuatan $f a$ 'il dengan proses peniadaan ( $a l-i$ 'dam), maka jawabnya adalah dari segi yang berkaitan dengan perbuatan $f a$ 'il dalam mewujudkannya, yakni mengeluarkan potensialitas menjadi aktualitas. Argumentasinyabegini, bahwa yang ada secara aktual adalah perusak bagi sesuatu yang potensial. Padahal, tiap-tiap yang potensial akan menjadi aktual kalau ada yang mengeluarkan potensinya sehingga menjadi aktual. Apabila yang potensial tidak maujud, maka tentu saja tidak ada $f a$ 'il sama sekali. Jika tidak ada $f a$ 'il, maka mesti tidak akan ada sesuatu yang aktual sama sekali. Oleh karena itu, dapat dikatakan bahwa keseluruhan susunan dan bentuk-bentuk itu "ada" secara potensial di dalam materi pertama, yaitu yang secara aktual menjadi Penggerak Pertama. ${ }^{2 s}$

\section{Penciptaan Secara Terus Menerus (al-Khalq al-Mustamir)}

Dalam banyak kesempatan, Ibnu Rusyd bukan hanya meluruskan pemahaman Ibnu Sina tentang prinsip-prinsip dalam teori emanasi. Lebih dari itu, juga menyatakan keberatannya terhadap emanasi itu sendiri. Menurut Ibnu Rusyd, teori emanasi Ibnu Sina masih mengandung kesulitan dan pertentangan pada segi kaidah-kaidah yang ada di dalamnya.

Oleh karena itu, Ibnu Rusyd mencoba menawarkan sutau teori penciptaan alam yang digali dari al-Qur'an dan filsafat Aristoteles. Menurut Ibnu Rusyd, sesungguhnya alam secara keseluruhannya diciptakan oleh Allah Swt. tidak secara sekaligus, tetapi berlangsung sejak azali, abadi dan berlangsung secara terus menerus. ${ }^{26} \mathrm{Hal}$ ini sebagaimana tercermin dari penjelasan Ibnu Rusyd, bahwa $f a$ ' $i l$ (yang mencipta sesuatu) ada dua macam:

Pertama fa'il yang darinya keluar maf ' $u l$, dan perbuatan fa' $i l$ tadi terkait erat dengan keadaan maf' ' $u l$. Jika telah sempurna keadaan maf' 'ulnya, maka maf 'ul tidak lagi memerlukan kepada fa 'il, seperti adanya rumah dengan tukang bangunannya. Kedua, fa'il yang darinya hanya keluar $f i^{\prime} l$, 
dan $f^{\prime} l$ inilah yang berhubungan dengan maf' $u l$. Maf 'ul tidak akan ada kecuali karena adanya hubungan fi'l dengan fa'il, dan adanya fa'il mengkhususkan kepada maf' 'ul bahwasanya perbuatan fa'il mengikuti adanya maf 'ul tersebut. Dalam artibahwa apabila $f i$ 'l tidak ada maka mof 'ul pun tidak akan pernah ada. Jika fi'l ada maka mof 'ul pun juga ada, yakni keduanya ada secara bersamaan. Keberadaan $f a$ 'il ini lebih utama dan termasuk yang memperoleh sifat aktual dari yang pertama, karena fa'il lah yang menciptakan maf 'ul dan yang memeliharanya. Ada juga $f a$ 'il lain yang menciptakan maf 'ul tetapi dia masih membutuhkan fa 'il yang lain lagi untuk menjaga maf' $u l$ yang diciptakannya. Demikianlah keadaan penggerak bersama gerakannya. Sedangkan segala sesuatu yang adanya dikarenakan oleh gerakan, maka ketika para filosof meyakini bahwa gerakan adalah perbuatan fa'il, dan bahwa wujud alam semesta tidak akan sempuma kecuali dengan adanya gerakan, maka mereka menyatakan bahwa hubungan $f a^{\prime} i l$ dengan gerakannya sama seperti hubungan $f a$ 'il terhadap alam. Seandainya perbuatan $f a{ }^{\prime} i l$ berhenti sekejap saja dari aktivitas geraknya, maka akan rusaklah alam semesta. ${ }^{27}$

Dari penjelasan tersebut tampak bahwa konsep penciptaan secara terus menerus merupakan kelanjutan dari ide penciptaan Aristoteles, bahwasanya Tuhan adalah Pengerak Pertama dan penciptaan dipahami sebagai proses penggerakan materi. Ketika gerakan tersebut berlangsung secara terus menerus maka dapat dipastikan penciptaan pun akan terus berlangsung. Dengan kata lain, penciptaan menurut lbnu Rusyd tidak bisa sempurna dalam satu tahap sekaligus, apalagi dari sesuatu yang tidak pernah ada sebelumnya. Sampai di sini, penciptaan dalam filsafat Ibnu Rusyd dapat juga dipahami sebagai proses merubah sesuatu agar menjadi sesuatu yang lain, atau merubah potensi dalam materi agar menjadi aktual di alam wujud. Keseluruhan proses tersebut berlangsung secara terus menerus dalam zaman yang sama, yakni sebelum zaman tak bermula. Ibnu Rusyd menegaskan bahwa qudrah Tuhan untuk menciptakan alam berlangsung secara terus menerus. Qudrah ini juga yang dipakai untuk memelihara alam setelah ia diciptakan dan menggerakkannya secara terus menerus pula. Dengan demikian, mudah dipahami bahwa alam memang kadim, abadi dan senantiasa bergerak secara terus menerus. Tetapi, harus segera pula dimengerti bahwa alan tetap mempunyai 'illah yang menciptakan dan menggerakkannya, yakni Allah Swt. yang sifat qadim-Nya berbeda dengan alam, sebab qadim bagi Allah tidak mempunyai 'illah apapun dan siapapun. 
Menurut Muhammad 'Imarah, alasan mendasar penolakan Ibnu Rusyd terhadap pandangan bahwa alam tercipta secara sekaligus, karena pandangan tersebut berdasarkan prinsip penciptaan dari tiada (creatio ex nihilo). Pandangan seperti ini mengandung konsekuensi bahwa wujud dan perbuatan al-Fa 'il al-Awwal (Tuhan) menupunyai permulaan. Jika perbuatan Tuhan berhubungan dengan ketiadan lalu dirubah menjadi ada, maka terjadi kemustahilan. ${ }^{28}$ Alasannya, perbuatan mencipta itu tidak akan pernah terkait dengan sesuatu yang tidak ada, karena sesungguhnya yang tiada tidak memiliki tempat dalam hubungan antara $f$ ' $/$ deng? fa'il, seperti halnya (sesuatu yang ada secara aktual) itu tidak akan pernah berhubungan dengannya suatu perbuatan atas dasar penciptaan. Kecuali, perbuatan al-Fa'il al-Awwal tersebut hanya berhubungan dengan hal ketiga-selain (ketiadaan) dan (wujud aktual)_yaitu sesuatu yang masih bersifat mumkin (wujud potensial). Hanya dari wujud yang terakhir inilah tercipta wujud aktual tadi. Jika penciptaan terjadi dalam keadaan sebaliknya, bahwa perbuatan fa'il berkaitan dengan maujud yang mungkin tidak adanya - sekiranya yang tiada ini mengikuti keterkaitan tersebut - maka hal yang seperti ini pun juga tercipta secara terus menerus. ${ }^{29}$ Perhatikan pernyataan Ibnu Rusyd berikut ini:

Sesungguhnya setiap yang baru adalah mumkin sebelum barunya, karena yang mumkin itu menghendaki sesuatu yang berada dengannya, dan yang mumkin adalah tempat penerimaan bagi sesuatu yang mumkin saja. Oleh karena itu, segala sesuatu yang bersifat mumkin dari segi penerimaannya, maka mesti diyakini bahwa ia juga mumkin dari segi fa'il... karena jelas bahwa sesungguhnya setiap satu bagian dari segala yang ada ini merupakan kerusakan (fasad) bagi sebagian yang lain, dan kerusakannya itu juga menjadi sebab bagi adanya yang selainnya lagi. Jika tidak demikian, adanya sesuatu itu bisa jadi bukan berasal dari sesuatu yang lain. Padahal, makna penciptaan itu sendiri adalah merubah sesuatu yang potensial menjadi aktual. Oleh karena itu, sesuatu yang tiada tidak mungkin berubah menjadi ada, dan tidak mungkin pula yang tiada tersebut disifati dengan ada. Yang saya maksudkan dengan perkataan tersebut adalah sesungguhnya alam ini diciptakan tetapi kekal, sebab adanya alam di sini berasal dari sesuatu yang dihasilkan karena adanya bentuk yang saling berlawanan, yaitu bentuk-bentuk yang berganti-ganti. ${ }^{30}$

Menurut 'Imarah, dalam filsafat Ibnu Rusyd sebenamya kontinyuitas, keazalian dan keabadian merupakan bagian dari aktivitas penciptaan, yakni merubah wujud potensial menjadi wujud aktual. Kekekalan wujud alam terkait erat dengan 
wujud al-Fa'il al-Awwal yang kadim. Sesungguhnya Pencipta Yang Esa, jika Dia memang azali maka perbuatan-Nya yang memberikan makna bagi keseluruhan mowjudat adalah perbuatan yang kekal, azali dan tidak ada dalam suatu masa selain masa ini. Maka, sesungguhmya fa'il yang perbuatannya berkaitan dengan mof' 'ul, ketika ia keluar dari potensialitas ke aktualitas adalah fa 'il yang muhdats dharuriy. Sedangkan al-Fa'il al-Awwal, maka dalam diri-Nya terdapat adanya keterkaitan dengan maf'ul secara kekal. ${ }^{31}$

Konsep pencipiaan alam secara terus menerus ini, menurut Ibnu Rusyd, jauh lebih mulia dari pada pencipran yang sempurna secara sekaligus tanpa ada pengulangan. Sebab, fa'il dalam perspektif ini tidak hanya bermakna sebagai pencipta alam, tetapi lebih dari itu sebagai pemelihara dan penggerak alam sebagai ciptaan-Nya secara terus menerus. Proses penciptaan, pemeliharaan dan penggerakan ini berlangsung sejak zaman tak bermula sampai tak terhingga. Dengan demikian, alam adalah taqaddum zamaniy walaupun ia memiliki 'illah yang menciptakannya, yakni Allah Swt. yang sama sekali tidak akan pernah mengabaikannya. Jadi, alam dalam pengertian ini adalah qadim yang senantiasa baru.

Dalam teori Ibnu Rusyd terlihat dengan jelas bahwa keseluruhan alam semesta ini tidak diciptakan, tidak diwujudkan dan tidak dibarukan dalam suatu rentang waktu yang telah ditetapkan. Tetapi, sesungguhnya penciptaan yang tergambar dalam kata-kata (ijad, khalq, tahownuul, tabdil, taghoyyur, tothawwur dan sebagainya) merupakan proses penciptaan yang bersifat azali, abadi dan berlangsung secara tenus menerus. Adapun yang dimaksud dengan huduts-nya alam, sebenamya bukan huduts bi al-jins (baru karena genusnya), atau huduts bi al-dzat (baru karena zatnya). Tetapi, huduts dalam pengertian ini adalah huduts bi al-ajza' (baru karena bagian-bagiannya). Sebab, materi alam ini kadim dan alamnya sendiri adalah azali. Kecuali itu, adanya alam dan kenusakannya yang abadi dan berlangsung terus menerus itu yang membedakan-nya dari baru dalam arti yang sebenamya. ${ }^{32} \mathrm{Hal}$ ini sebagaimana dinyatakan dalam Tahafut al-Tahafut:

Arah keluarnya yang baru dari yang (kadim pertama) bukan dikarenakan ia adalah baru, tetapi karena ia azali genusnya dan baru bagianbagiannya. Hal itu dikarenakan adanya suatu anggapan bahwa setiap fa'il yang kadim apabila keluar darinya sesuatu yang baru, maka dia bukan fa 'il yang kadim pertama lagi, sebab perbuatan fa 'il itu mesti berpegang kepada yang kadim pertama. ${ }^{33}$ 
Dengan demikian, hukum bagi fa 'il yang kadim dan azali juga berlaku bagi perbuatannya yang azali karena dzat atau genusrya Atas dasar itu, tidak dapat dibenarkan argumen kaum teolog yang mempertahankan ke-gadim-an fa'il dan ke-huduts-an perbuatannya. Alasannya, genus atau dzat sebagai yang dimaksudkan huduts di sini dikarenakan bagian-bagiannya saja.

Senada dengan alasan tersebut, Ibnu Rusyd menambahkan, apabila fa'il melakukan suatu perbuatan maka sesungguhnya ia berhubungan dengan maf'ul dalam segi adanya keterkaitan bahwa maf'ul itu yang tergerakkan. Gerakan dari wujud potensial ke wujud aktual inilah yang dinamakan oleh Ibnu Rusyd dengan huduts. Apabila wujud yang azali itu lebih berhak untuk eksis dari pada maujud yang bukan azali, maka begitu juga sesuatu yang diciptakan sejak azali itu lebih utama untuk menyandang predikat ihdots (penciptaan) dari pada sesuatu yang penciptaannya pada waktu-waktu tertentu saja. ${ }^{34}$ Sesungguhnya, gerak perubahan dari wujud potensial ke wujud aktual ini yang dianggap sebagi penciptaan oleh Ibnu Rusyd. Penciptaan menurutnya adalah azali, karena ia tidak diciptakan dalam masa tertentu. Maksud Ibnu Rusyd tentang penciptaan di sini tidak lain adalah penciptaan alam.

\section{E. Penutup}

Dari ulasan filsafat Ibnu Rusyd tentang kosmologi di atas ada kesan bahwa Ibnu Rusyd banyak dipengaruhi oleh madzhab Aristoteles. Dalam konteks ini, Ibnu Rusyd bermaksud meluruskan filsafat "guru pertama" asal Yunani tersebut yang telah disalahmengerti oleh lbnu Sina, sehingga dikecam Imam al-Ghazali. Tetapi, di balik alasan ini sebenarnya filosof muslim Cordova dan penganut madzhab Maliki di bidang figh itu hanya ingin menghidupkan kembali cahaya filsafat yang pada saat itu semakin meredup. Usaha lbnu Rusyd terbukti tidak sia-sia, sebab setelahnya muncul para filosof muslim seperti Ibnu Thufail, Ibnu Bajah, Ibnu Khaldun dan lain-lain. Bahkan, umat Islam sekarang pun masih dapat menikmati panorama filsafat itu, meskipun tidak seindah di Barat.

Apapun pandangan filosofis yang ada dalam tulisan ini hanyalah wujud dari ketidakberdayaan seorang hamba untuk memahami kemahabesaran Tuhannya. Oleh karena itu, sama sekali lbnu Rusyd juga tidak bermaksud mengatakan bahwa 
pemikirannya adalah realitas penciptaan alam yang sebenamya. Filsafat Ibnu Rusyd tentang kosmologi ini tidak lebih dari sekadar hasil ijtihad seorang manusia. Hakikat kebenarannya hanya Allah Swt. yang mengetahui dan memilikinya. Wallahu a 'lam bi al-shawab

\section{Endnotes}

Madjid Fakhri, A History of Islamic Philasophy, (New York: Columbia University Press, 1988), hal. 302

M. Yusuf Musa, Bain al-Din wa al-Falsafah fi Ra yi Ibni Rusyd wa Falasifah al'Ashr al Wasith, (Beirut: al-Ashr al-Hadits li al-Nasyr wa al-Tauzi', 1998), hal. 45-47 Harun Nasution, Islam Resional:Gagasan dan Pemikiran, (Bandung: Mizan, 1996), hal. $43-44$

Ibnu Rusyd, Tahafut al-Tahafut, dalam Sulaiman Dunya (Ed.), (Kairo: Dar al-Ma'arif, 119 H.) hal. 83

Ibid. hal. 222

Ibru Rusyd, Fashl al-Magal fi Ma bain al-Hikmah wa al-Syari 'ah min al-Itlishal, dalam Muhammad 'Imarah (Ed.), (Kairo: Dar al-Ma'arif. 119 H.). hal. 42-43

Ibid., hal. 43

Sayyid Syarif al-Jurjani, al-Ta 'rifat, (Istambul: t.p., 1327 H.), hal. 56

- Ibnu Rusyd, al-Manahij... op. cit., hal. 79

1". Ibnu Rusyd, al-Fashl ....op. cit., hal. 42

1 Ibnu Rusyd, Tahafiul al-Tahafiut ......op. cil., hal. 275-276

12 Ibid, hal. 290

13 Ibnu Rusyd, Tahofut al-Tahafut ....op. cit., hal. 191

14 Ibid, hal. 232

is Zairab Mahmud Khudairy, Alsces Ibni Rusjd fi Falsojah al- 'Ushur al-Wustha, (Beirut: Das al-Tanwir li al-Thaba'ah wa al-Nashr, 1985), hal. 231

16 Ibid

17 Ibid., hal. 233

18 Ibnu Rusyd, al-Fashl ....op. cit., hal. 43

19 Ibnu Rusyd, al-Kasys 'an Manahij al-Adillah fi 'Agaid al-Millah, (Bairut: Dar al-Afak al-Jadidah, 1978), hal. 106-107

20 Ibid., hal. 107

Ulul Albab, Vol. 4 No. 2, 2002 
21 Zainab Mahmud Khudairy, op. cit., hal. 235

22 Ibid., hal. 236

23 Muhammad 'Imarah, Al-Madiyah wa al-Matsaliyah fil Falsafah Ibni Rusyd, (Kairo: Dar al-Ma' arif, 1971), hal. 60-64

24 Ibid., hal. 68

25 Ibid.

26 Muhammad 'Imarah, op. cit., hal. 65

27 Ibnu Rusyd, Tahafut al-Tahafut. ..op. cit., hal. 428-429

28 Muhammad 'Imarah, loc. cit.

29 Ibid.

30 Ibnu Rusyd, Tahafut al-Tahafut...op. cit., hal. 191

31 Muhammad 'Imarah, op. cit., hal. 66. Lihat juga Ibnu Rusyd, ibid., hal. 520

32 Muhammad 'Imarah, ibid., hal. 65-68

33 Ibnu Rusyd, Tahafut al-Tahafut... op. cit., hal. J35

34 Ibid., hal. 283-284 


\section{Bibliography}

Harun Nasution, Islam Rasional: Gagasan dan Pemikiran, (Bandung: Mizan, 1996)

Ibnu Rusyd, Tahafut al-Tahafut, dalam Sulaiman Dunya (Ed.), (Kairo: Dar alMa'arif, $19 \mathrm{H}$.)

_- Fashl al-Magal fi Ma bain al-Hikmah wa al-Syari'ah min al-Ittishal, dalam Muhammad 'Imarah (Ed.), (Kairo: Dar al-Ma'arif, 119 H.)

—_, al-Kasyf 'an Manahij al-Adillah fi 'Agaid al-Millah, (Bairut: Dar alAfak al-Jadidah, 1978)

Madjid Fakhri, A History of Islamic Philosophy, (New York: Columbia University Press, 1988)

M. Yusuf Musa, Bain al-Din wa al-Falsafah fi Ra'yi Ibni Rusyd wa Falasifah al- 'Ashr al Wasith, (Beirut: al-Ashr al-Hadits li al-Nasyr wa al-Tauzi', 1998)

Muhammad 'Imarah, Al-Madiyah wa al-Matsaliyah fil Falsafah Ibni Rusyd, (Kairo: Dar al-Ma'arif, 1971)

Sayyid Syarif al-Jurjani, al-Ta'rifat, (Istambul: t.p., 1327 H.)

Zainab Mahmud Khudairy, Atsaru Ibni Rusyd fi Falsafah al-'Ushur al-Wustha, (Beirut: Dar al-Tanwir li al-Thaba'ah wa al-Nashr, 1985) 